\title{
Influence of Method on the Apparent Size Distribution of Bacterioplankton Cells: Epifluorescence Microscopy Compared to Scanning Electron Microscopy
}

\author{
J. A. Fuhrman
}

Institute of Marine Resources, A-018, Scripps Institution of Oceanography, University of California, San Diego, La Jolla, California 92093, USA

\begin{abstract}
Size distributions of unattached marine bacterioplankton determined by epifluorescence microscopy were compared with those determined by scanning electron microscopy (SEM). Significant (up to $37 \%$ ) and variable linear shrinkage occurred during preparation for SEM. Therefore, though far from perfect, epifluorescence microscopy of wet preserved cells is probably more accurate than SEM for determination of size and biovolume. Comparison of the distribution of bacterial size with literature data for the distribution of bacterial activity suggested that the small to medium. sized bacteria $(<0.6 \mu \mathrm{m}$ diameter) are much more active, on a per unit volume basis, than larger bacteria.
\end{abstract}

Reliable calculation of biomass of marine bacterioplankton is based on accurate measurement of bacterial cell size. In much of the work done to date (Ferguson and Rublee, 1976; Bowden, 1977; Watson et al., 1977; Zimmermann, 1977; Fuhrman and Azam, 1980; Fuhrman et al., 1980) average cell volume has been used to estimate bacterial biomass. Cell sizes were determined by a variety of microscopic methods, including measurement of wet preserved cells by epifluorescence microscopy, measurement of dried preserved cells or carbon replicas by electron microscopy, and visual classification into specific size categories; the accuracy of these methods has not been critically evaluated. Such studies have also tended to ignore the size distribution of bacterioplankton cells, except for classification into a few broad size categories; it is desirable to know size distribution more accurately for studies of selective grazing by bacteriovores and the determination of the bacterioplankton contribution to optical properties of seawater.

Scanning electron microscopy (SEM), although a convenient and esthetically pleasing technique for the study of cell morphology, may underestimate cell sizes. It is known that drying steps during SEM specimen preparation can cause significant and variable shrinkage in eucaryotic tissues (see Hayat, 1978 and references therein). Recent work (Trueba and Woldringh, 1980) shows that cells of the bacterium Escherichia coli dried by the critical point method and viewed by electron microscopy appear to have about one half the diameter of similar cells viewed wet by phase contrast microscopy. Shrinkage of dried marine bacterioplankton, even to a lesser extent, could have a drastic effect on volume estimates, since volume varies as the cube of linear dimension.

Boyde (pers. comm., cited in Zimmermann, 1977) suggested that the large surface-to-volume ratios of bacterioplankton prevent significant size alteration during drying with alcohols and Frigen, but it is not clear how universally this applies. In the present study, the apparent size distributions of marine bacterioplankton, as compared by SEM and epifluorescence microscopy, reveal that significant shrinkage of these organisms can occur during preparation for SEM.

Samples for this study were collected either near the surface off Scripps Institution of Oceanography Pier on 26 August 1980 or from $34 \mathrm{~m}$ depth at Southern

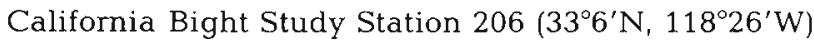
on 19 October 1980 (region described in Eppley et al., 1978). Samples were immediately preserved by addition of filtered, borate-buffered formalin to a final concentration of $4 \%$. The Scripps Pier sample was prepared for SEM and epifluorescence microscopy after $4 \mathrm{~h}$ of preservation and the California Bight sample was stored in the dark at $\sim 20^{\circ} \mathrm{C}$ for 3 weeks and prepared shortly after return to shore. For SEM preparation, the samples were filtered through $0.2 \mu \mathrm{m}$ pore size Nuclepore filters (13 $\mathrm{mm}$ diameter); the cells on the filter were transferred to distilled water via 75,50 , and $25 \%$ filtered seawater in distilled water, and then dehydrated in $50,75,85,95,100$, and $100 \%$ ethanol; 
50, 100 and $100 \%$ Freon 113 in ethanol and finally critical point dried in Freon 13 (Cohen et al. 1968). The dried filters were sputter coated with $15 \mathrm{~nm}$ Au-Pd, and viewed in a Cambridge Stereoscan S4 SEM at 3600-8200x.

For epifluorescence microscopy (largely according to Hobbie et al,, 1977) samples were stained for $1 \mathrm{~min}$ with $2.5 \mu \mathrm{g} \mathrm{ml}^{-1}$ (final concentration) filtered acridine orange, filtered through a black-stained $0.2 \mu \mathrm{m}$ pore size Nuclepore filter (25 mm diameter), transferred on the wet filter to a slide, covered with paraffin oil and a coverslip, and viewed at $1000 \mathrm{X}$ (oil immersion) on a Zeiss epifluorescence microscope with catalog \# 487709 filter set. Cells were photographed on Kodak Tri-X or Panatomic-X $35-\mathrm{mm}$ films. The photographs were enlarged to $3200 \mathrm{X}$ (magnification determined from photographs of a calibrated micrometer) for measurement of bacterioplankton size. Bacterioplankton size was measured with a magnifier marked at $0.1 \mathrm{~mm}$ intervals. Cells were categorized into spheres (volume $=4 / 3 \pi \mathrm{r}^{3}$ ) and rods (cylinders with hemispherical caps, volume $\left.=\pi r^{2}[L-2 / 3 r]\right)$. Volume and distribution data were analyzed by computer. The data apply only to free-living bacteria, because we did not specifically look for attached forms or aggregates which are rare in our study area.

The results (Table 1) show that the SEM estimates of average bacterial volume were smaller than those made with epifluorescence microscopy. The difference was statistically significant ( $t$-test, $P<.05$ ) for the Pier sample, but not for the Bight sample. Had the cells all been spheres, the apparent difference in average volumes would be equivalent to a diameter difference of $37 \%$ and $11 \%$ in the Pier sample and the California Bight sample, respectively. It is likely that the observed differences between methods is due to shrinkage of bacterioplankton during SEM preparation. Nevertheless, the potential problems with size estimates made with epifluorescence microscopy should not be overlooked. Viewed directly through the microscope, the bacteria appear to have sharply defined boundaries, but many are too small to measure directly with accuracy. This problem is alleviated by taking photographs of the bacteria and making enlargements, but under these circumstances many of the images lose their sharp boundaries due to film grain and slight focussing problems. In some instances it is also difficult to distinguish between small cells and bits of stained detritus. These problems are likely to decrease the precision of estimates made with epifluorescence microscopy, and should be kept in mind.

When examining the results, one should also keep in mind that $0.2 \mu \mathrm{m}$ pore size filters were used to collect the bacteria. Thus, some very small bacteria were probably missed. Zimmermann (1977) estimates that this filter size misses $10 \%$ of the total bacteria, containing a few percent of the bacterial biomass. Therefore, the error introduced is probably slight.

Fig. 1 shows the apparent size distribution of bacterioplankton as determined by the two methods. Due to the small number of bacteria in some size classes, the curves are probably not exact representatives of the two distributions, but they are adequate for the current purposes. The data were subjected to mock shrinkage: the size of each bacterium as viewed by epifluorescence microscopy was mathematically 'shrunken' by the average apparent shrinkage for that sample. The shape of the distribution of mathematically 'shrunken' cells is similar to that of the cells observed by SEM. This further supports the claim that SEM preparation causes shrinkage. The curve for the Pier sample shows that the distribution of mathematically 'shrunken' cells is skewed slightly to the left of the distribution of cells observed by SEM. This skewness may be due to disproportionately greater shrinkage by the larger cells, which have lower surface to volume ratios, although shrinkage in all size classes is still apparent. Alternatively the cells viewed by epifluorescence may possibly appear proportionately larger than they really are, but unlike the shrinkage hypothesis, this possibility is not supported by any outside evidence.

It is not known why the Pier sample appeared to shrink more than the California Bight sample. Possible factors include (1) physiological differences between the bacteria in the samples, such as different polymer or water content; (2) different preservation times, and

Table 1. Volume distribution statistics

\begin{tabular}{|c|c|c|c|c|c|c|c|c|c|c|c|}
\hline \multirow[b]{2}{*}{ Sample } & \multirow[b]{2}{*}{ Method } & \multirow[b]{2}{*}{ Cells $\mathrm{ml}^{-1}$} & & \multicolumn{3}{|c|}{ Volumes $\left(\mu \mathrm{m}^{3}\right)^{*}$} & \\
\hline & & & $\mathrm{N}$ & $\underset{\bar{x}}{\text { sphere }}$ & $S E$ & $\mathrm{~N}$ & $\begin{array}{c}\text { Rods } \\
\bar{x}\end{array}$ & $\mathrm{SE}$ & $N$ & $\frac{1}{x}$ & $\mathrm{SE}$ \\
\hline Pier & Epifl. & $3.26 \times 10^{6}$ & 102 & 113 & .017 & 97 & 178 & .029 & 199 & 145 & .017 \\
\hline Pler & SEM & & 80 & .032 & .004 & 86 & .040 & .005 & 166 & .036 & .003 \\
\hline Bight & Epifl. & $5.76 \times 10^{5}$ & 112 & .088 & .027 & 96 & .073 & .006 & 208 & .081 & .015 \\
\hline Bight & SEM & & 113 & .075 & .015 & 114 & .040 & .005 & 227 & .058 & .008 \\
\hline
\end{tabular}




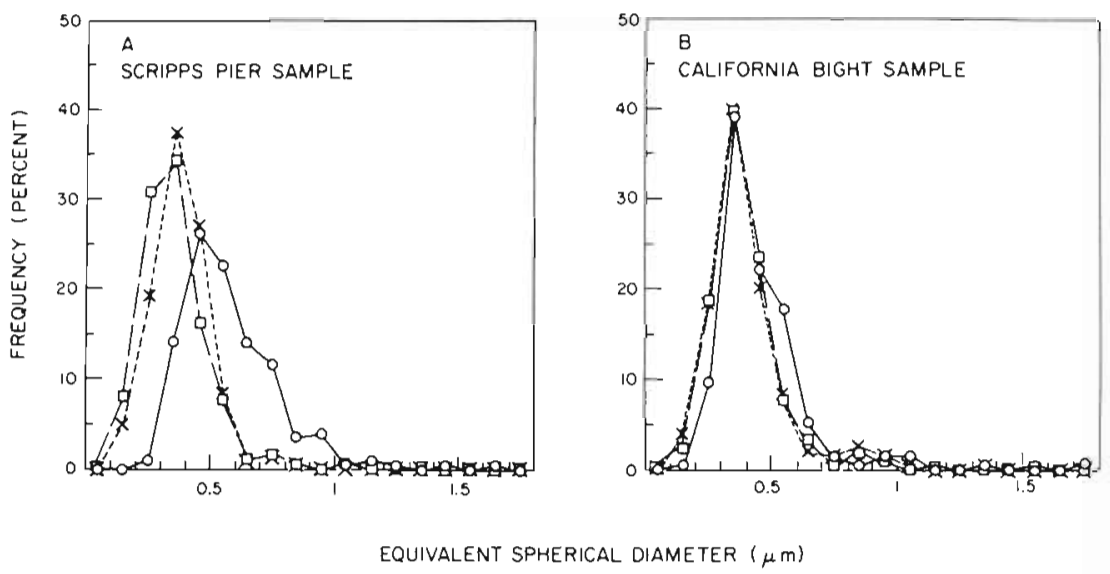

Fig. 1. Apparent size frequency distributions of bacterioplankton, plotted as percent of the total number of cells in a particular size class versus the mean equivalent spherical diameter of that size class. O epifluorescence microscopy; $\square$ epifluorescence microscopy with each individual shrunken proportionally to obtain same mean volume as SEM estimate; $\times$ SEM
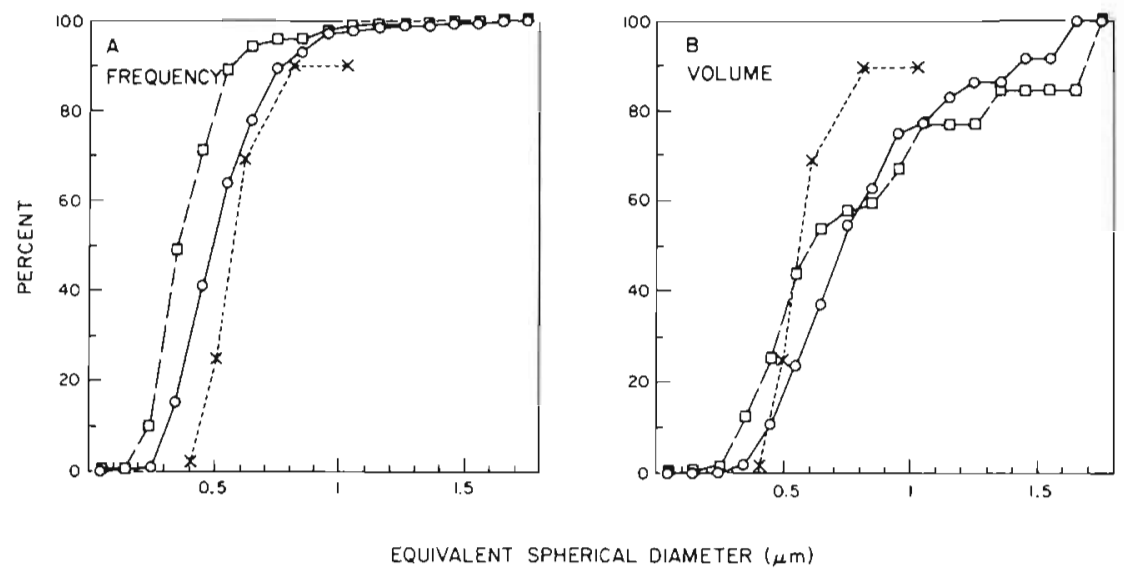

Fig. 2. Cumulative frequency and volume distributions of bacterioplankton determined by epifluorescence microscopy. (A) cumulative percent frequency (each cell given equal percentage); (B) cumulative volume (each cell's percentage proportional to its volume). O Pier sample; $\square$ Bight sample; $\times$ percent passage of ${ }^{3} \mathrm{H}$ glucose uptake plotted against filter pore size (after Azam and Hodson, 1977)

(3) slight differences in the drying procedure. In any event, critical point drying $\mathrm{can}$ cause significant shrinkage of marine bacterioplankton. Thus, unless a certain drying procedure is consistently shown to cause negligible shrinkage, it is unwise to dry samples before size measurements.

Plots of the cumulative frequency and volume distributions, as determined by epifluorescence microscopy (Fig. 2) show that, as expected, the rare large cells account for a large proportion of the total volume; more than one-fifth of the total volume of 208 cells measured in the California Bight sample was made up by two cells. Thus the shape of the right portions of the curves in Fig. 2B (i.e. past $0.8 \mu \mathrm{m}$ equivalent diameter) are discontinuous due to the small number of bacteria represented; these portions of the curves should therefore be considered approximations. The left portions of these curves (i.e. below $0.8 \mu \mathrm{m}$ equivalent diameter) are derived from a much larger number of measurements and are probably much more accurate. Determining the accurate cumulative volume distribution of the whole bacterioplankton population of a given sample would require measurement of several thousand individual bacteria, and is beyond the scope of this study, and the curves presented here only serve to illustrate the general shape of the distributions.

The frequency and volume distributions of bacteria determined microscopically can be compared to the size distributions of bacterial activity measured by uptake of labeled organic compounds and differential filtration (Azam and Hodson, 1977). Such a comparison (Fig. 2) shows that activity more closely follows bacterial numbers (Fig. 2A) than the bacterial volume (Fig. 2B). In fact, the similarity between the size distribution of activity and that of bacterial numbers is probably closer than it appears from Fig. 2A because the 
reported activity measurements in the $<0.4 \mu \mathrm{m}$ and $<0.5 \mu \mathrm{m}$ size fractions are atypically low; commonly, $20-40 \%$ of the total bacterial uptake activity can pass through $0.4 \mu \mathrm{m}$ pore size Nuclepore filters (Azam, pers. comm.). These distribution data suggest that the various sizes of bacteria have roughly equal activity on a per cell basis. On a unit volume basis, however, the small to medium sized bacteria $(<0.6 \mu \mathrm{m}$ diameter $)$ are much more active than the rare large bacteria. Azam and Hodson (1977) come to a similar conclusion based on ATP measurements; certainly such observations are not in accord with the notion that the smaller marine bacterioplankton are relatively inactive or 'dormant'.

Acknowledgements. I thank E. Stewart for assistance with computer programming, and Dr. F. Azam for helpful discussion. J. Ammerman and S. Horrigan kindly reviewed the manuscript.

This work was supported by DOE Contract DE-AM0376 SF00010 (SCBS) and NSF grant OCE79-26458.

\section{LITERATURE CITED}

Azam, F., Hodson, R. E. (1977). Size distribution and activity of marine microheterotrophs. Limnol. Oceanogr. 22: 492-501

Bowden, W. B. (1977). Comparison of two direct count techniques for enumerating aquatic bacteria. Appl. environ. Microbiol. 33: 1229-1232

Cohen, L., Marlow, P., Garner, G. E. (1968). A rapid critical point method using fluorocarbons ("Freons") as inter- mediate and transitional fluids. J. Microsc. (Paris) 7 . $331-342$

Eppley, R. W., Sapienza, C., Renger, E. H. (1978). Gradients in phytoplankton standing stocks and nutrients off Southern California in 1974-1976. Estuar. coast. mar. Sci. 7: 291-301

Ferguson, R. L., Rublee, P. (1976). Contribution of bacteria to standing crop of coastal plankton. Limnol. Oceanogr. 21: $141-145$

Fuhrman, J. A., Ammerman, J. W., Azam F. (1980). Bacterioplankton in the coastal euphotic zone: distribution, activity, and possible relationships with phytoplankton. Mar. Biol. 60: 201-207

Fuhrman, J. A, Azam, F. (1980). Bacterioplankton secondary production estimates for coastal waters of British Columbia, Antarctica, and California. Appl. environ. Microbiol. 39: 1085-1095

Hayat, M. A. (1978): Introduction to biological scanning electron microscopy, University Park Press, Baltimore

Hobbie, J. E., Daley, R. J., Jasper, S. (1977). Use of Nuclepore filters for counting bacteria by fluorescence microscopy. Appl. environ. Microbiol. 33: 1225-1228

Trueba, F. J., Woldringh, C. (1980). Changes in cell diameter during the division cycle of Escherichia coli. J. Bacteriol. 142: 869-878

Watson, S. W., Novitsky, T. J., Quinby, H. L., Valois, F. W. (1977): Determination of bacterial number and biomass in marine environments. Appl. environ. Microbiol. 33: 940-946

Zimmermann, R. (1977). Estimation of bacterial number and biomass by epifluorescence microscopy and scanning electron microscopy. In: Rheinheimer, G. (ed.), Microbial ecology of a brackish water environment. Springer Verlag, Berlin, pp. 103-120

Accepted for printing on February 23, 1981 